\title{
The development of agricultural production in Finland 1975-85
}

\author{
LAURI KetTUnen \\ Agricultural Economics Research Institute, Rukkila, 00001 Helsinki 100
}

\begin{abstract}
Forecasts of the production of main agricultural products until 1985 are based on an assumption that slightly lower targets for self-sufficiency of each product will be maintained in the future. Internal factors are also taken into account in estimating the evolution of agricultural production in the 1980 's.

Milk production is predicted to drop to 2910 mill. litres, beef production to 105 mill. kg. and egg production to 70 mill. kg. by 1985 . Comsumption of pork is increasing and, therefore, the pork production is estimated to rise to 180 mill. kg. Similarly, the prospects for poultry meat are good as the production is forecasted to increase to 25 mill. kg. by 1985 .

There forecasts imply that the volume of agricultural production will remain quite stable. Since the yields in crop production are expected to increase by 1.5 per cent per year, overproduction would likewise seem to rise. However, the cultivated area has decreased and evidently will decrease further in the future due to policy measures aimed at curtailing the growth of production. Consequently the overproduction situation will not deteriorate very much from what it is at present.
\end{abstract}

\section{Introduction}

\section{Forecasting in general}

Forecasts of agricultural production are based mostly on capital and labour resources, arable land and producer prices. A commonly optimal allocation or profit maximization is assumed. Forecasts are often made by using mathematical means such as econometric models or optimization methods.

Forecasts of agricultural production in Finland cannot be made using the above mentioned methods alone, because of measures taken to curtail production or attemps at such measures. Since the end of the 1960's, soil bank or fallowing systems have been applied, dairy cows have been slaughtered, the establishment of poultry yeards and piggeries have been restricted, production fees have been levied on fertilizers and feeding stuffs, and marketing fees have been levied on pork, milk and wheat in order to curtail production. The aim has been to make production more clocely adjusted to the domestic demand. The possibilities for a free development of production have been limited despite an abundance of resources.

Production control measures are evidently going to characterize our agricultural policy in the future. The degree of self-sufficiency of our main 
products exceeds 100 per cent at the moment. World market prices will rise only slightly in the coming years so that advantageous exports of agricultural products cannot be forecasted. It is consequently necessary to reduce production. Employment, food supply and general social policy speak, however, in favour of slight overproduction.

The development of agricultural production is thus going to depend on public policy measures. Production or export limits laid down by law are evidently going to have a special significance in the development of production. In the income law of 1977, there are provisions which fix production or export ceilings for milk, meat, eggs and grain production. If these are exceeded, the agricultural sector has to finance the extra exports. It may be assumed that agriculture will try to adjust production in accordance with the ceilings in order to minimize the costs caused by the ceiling system. Annual fluctuations are, of course, possible owing to crop variations.

The government is partly responsible for the adjusting of production to targets which are not production limits; they only define the roles of the state and the agricultural sector in the marketing of overproduced commodities. The production potential has been reduced or the production shifted from one product to another by many legal measures. The total production of our agriculture depends largely on the efficiency and the scope of these measures.

Forecasting agricultural production in Finland differs considerably from that in many other countries. It is more common for where the development of production to be limited by a scarcity of resources. Often, the problem lies in getting production to grow sufficiently rapidly.

Even though the forecasting of agricultural production is tied to production targets there are some areas for which conventional forecasts are possible. One of the most important factors of the production potential is the crop yield level, which is not greatly affected by agricultural policy measures. By regulating fertilizer prices it is possible to direct the use of fertilizers and thus, partly, the yield level. This can be taken into account in the forecasts.

Another possible objective in forecasting is determining the feed use efficiency rate in animal production. By breeding it is now possible to produce animals which are able to use feed more efficiently than earlier. Feeding methods are also improving all the time. These factors increase the production potential.

By combining the crop yield and feed efficiency rate forecasts, an overall picture of the development possibilities of Finnish agriculture is obtained. The final magnitude of the production depends, however, on the agricultural policy practised. Since there is no long-term agricultural programme, forecasts have to be based on different assumptions. The greatest problems are associated with arable land and animal production.

\section{Forecasting methods}

Long-term forecasts are usually made by methods which are much simpler than those used for short-term forecasts. One reason for this lies in the structural change, the effect of which cannot easily be quantified, which prevents estimation of the changes in structural parametres. 
It is not necessary here to try to review long-term forecasting methods in general. Only the methods used in this study will be briefly presented.

The forecasts are mainly projections. There may not be any clear definition for projections or trend forecasts. In practice projections are made by utilizing past development. Very often projections are made assuming that:

a) the underlying factors remain constant

b) these factors develop as earlier

c) the policy is stable

These assumptions may, in fact, be rather indefinite or inaccurate, for distinguishing between the different factors is difficult. In addition, development may not be stable due to vigorous policy measures or developments which have been practised only at some time.

Trend forecasts are mostly linear extrapolations. The trend line, measured by the eye, or the method of least squares, is projected for the future. Of course, a curved path may also be used. The forecast may then be based on a linear trend which is curved on the basis of different factors. A trend like that may be, or may seem to be, better than a forecast made by using mathematical methods, for the latter are often too formal or may not take into account all factors. It may also be difficult to include restricting factors in the mathematical models, even though they would be decisive for the whole development.

Long-term forecasts are not intended for use during the whole forecasting period, but since they depict the development at the moment when the forecasts are made, they should be checked every two years.

In this paper, forecasts of agricultural production up to 1985 are presented. Separate forecasts have been made for concumption, crop yield and feed efficiency rates (Haggren and Kettunen 1976, Mela and Haapalainen 1976, HaApa and Maijala 1977, Haggren 1977, Kettunen 1977). Only the forecasts for animal production are new in this study. The article is a summary of a research project which the Agricultural Economics Research Institute, the Department of Plant Husbandry, the Department of Animal Husbandry of the Agricultural Research Centre and the Board of Agriculture have carried out jointly. The Ministry of Agriculture and Forestry has supported the project with special funds. This article has also been published in Finnish (Kettunen 1978).

\section{Plant production}

\section{Crop yield forecasts}

Plant production is the basis for total agricultural production since imports of feed account for only $2-\mathbf{5}$ per cent of the feed input, (and the government hopes to reduce them still further). The development of total production is very closely related to plant production.

The Department of Plant Husbandry of the Agricultural Research Centre has made forecasts of the yields of the main crops (Mela and HaApalainen 1976). The products presented in Table 1 cover about 95 per cent of all plant production. 
Table 1. The yields for main crops in 1975 and 1985.

\begin{tabular}{|c|c|c|c|}
\hline & $\left.1975^{1}\right)$ & 1985 & Change \\
\hline & \multicolumn{2}{|c|}{ kg per ha } & per cent \\
\hline Winter wheat ................... & 3020 & 3280 & 9 \\
\hline Spring wheat $\ldots \ldots \ldots \ldots \ldots . . . .$. & 2680 & 3040 & 13 \\
\hline 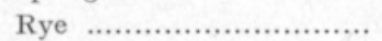 & 2210 & 2670 & 21 \\
\hline Barley ......................... & 2510 & 2950 & 18 \\
\hline 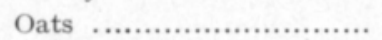 & 2470 & 2900 & 17 \\
\hline 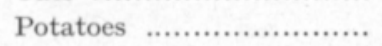 & 14030 & 19500 & 39 \\
\hline Sugar beet $\ldots \ldots \ldots \ldots \ldots \ldots$ & 29700 & 33000 & 11 \\
\hline Hay (dried) ................... & 3910 & 4300 & 10 \\
\hline Silage $\ldots \ldots \ldots \ldots \ldots \ldots \ldots \ldots$ & 19190 & 21500 & 12 \\
\hline
\end{tabular}

1) Trend values from years $1971-75$.

Crop yield forecasts are not made by a strictly formal method, but different research results, field experiments etc., in addition to subjective considerations and the views and opinions obtained from different sources, are applied. This kind of mixed method was chosen owing to the fact that mathematical models cannot easily account for all factors such as the rapiod rise of fertilizer prices. It is possible that the growth rate of the biological-technical development will be underestimated, which has often been the case.

In this connection it is not possible to deal in detail with the factors affecting crop yields and a few general comments may suffice. The use of fertilizers is assumed to continue to increase samewhat, even though fertilizer sales have dropped as a result of the rise in its price. The improvement of fertilizing methods may also raise the yields. Plant breeding may be considered independent of economic development so that it will lead to new varieties with higher yields. The spread of existing new varieties also guarantees a certain increase in the yields.

The use of different pesticides and chemicals, as well as irrigation, will also increase the yields. Drainage, improved skills, etc. can also be included in this list. Weather is an important factor in causing fluctuations in yields, it cannot be forecasted, however. The projections have, therefore, been based on normal yields.

The forecasts show relatively small increases in the yields. In fact, they were reached as early as 1976 as a result of favourable weather conditions. The average increase in the yield depends on the area allotted to the various crops in 1985. Using the areas for 1975, the increase in yields is, on the average, 15 per cent or $\mathbf{1 . 5}$ per cent per year.

\section{Animal production}

\section{Background of forecasts}

The production forecasts presented below are based on the production ceilings or targets valid at the moment. Production limits are only set for $1979-81$, but it is assumed that the policy will not have changed much by 
1985. The production ceilings are partly based on the consumption forecasts made in 1975 (Haggren and Kettunen 1976, Kettunen 1976). Since economic growth has been about nil, the consumption forecasts may not materialize. For example, the increases in the consumption of meat and cheese, which are income responsive, may be slower than forecasted.

The development of the concumption is a crucial point when production forecasts are made. It can be assumed that overproduction will be curbed in the future owing to the state financial situation. It may not be possible to allow self-sufficiency levels of the final products to increase, more likely the tendency will be to lower them. The possibilities for the development of production are thus tied to those of consumption.

However, if measures to curtail the growth of production are abandoned for example, in order to avoid unemployment which is associated with a decrease in agricultural production, the production forecasts presented below will not prove accurate. No facts indicate at present that total production would fall in the future.

\section{Milk production}

\section{1. The number of dairy cows}

The forecast of milk production is based on separate estimates of the number of dairy cows and the average yield per cow. The development of the number of dairy cows has not been linear, so no uniform trend can be found. The general trend runs, however, clearly downwards. In recent years several steps have been taken which have been contradictory to each other, consequently, it is difficult to set up the background assumptions. In 1969, severe measures (slaughtering payments) were applied to curtail production. In the beginning of the 1970's people were worried about the decrease in milk production and so the producer price of milk was raised considerably. This evidently slowed down the decrease in milk production. After the milk production had turned to a slight growth in 1976, the time had again come to stop the development. The producer price was raised a little, marketing fees were collected and, finally, an upper limit for the quantity of milk marketed was established. This means that farmers must export their excess production at their own expense.

Since the reactions of the farmers in milk production are slow to materialize it is not possible to see yet what the final results of the recent policy measures will be and so it is not easy to make any sound assumptions for the forecasts of milk production. The only way seems to be to try speculating on what will be done in the future.

It can be seen (Figure 1) that the number of dairy cows started to decline in 1964. As from that year, a forecast of 500000 dairy cows in 1985 can be made. In the 1970's, the decline has been much slower, $21000-22000$ cows per year compared to 40000 in the 1960 's. In recent years it has only been 10000 cows per year.

Should the trend forecast be made to begin as from 1963 or from 1970? That question cannot be answered. The desire to keep overproduction within 


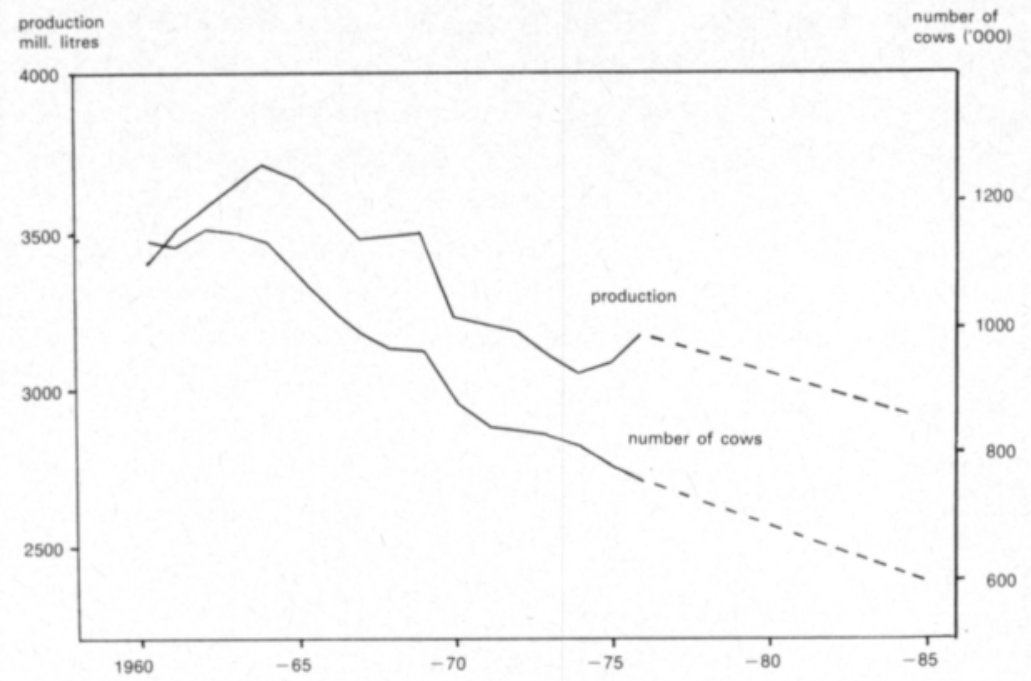

Figure 1. The number of dairy cows and milk production in $1960-76$ and forecasts for 1985.

manageable limits has evidently directed the development of the milk production. This policy will obviously prevail in the future, as indicated by the proposals made by the special committee working on long-term production targets.

The 1970's seem to be the suitable basis for the projection. With that as the starting point, the decline in the number of dairy cows has been rather linear. This leads to a forecast of 600000 cows in 1985 . However, this estimate requires further consideration.

\section{2. Average milk yield}

The average milk yield per cow increased rather linearly in the 1960's. But in the 1970's the development has been uneven, which hampers the forecast. The variation in the yield was caused by the poor quality of the fodder (hay) and, indeed these poor years may be ignored when the projection is made. A forecast of 4850 litres per cow is obtained for 1985:

$\begin{array}{lrrrrrrr}\text { Year } & 1960 & 1965 & 1970 & 1972 & 1974 & 1976 & 1985 \\ \text { Yield 1/cow ................ } & 2955 & 3277 & 3480 & 3889 & 3856 & 4200 & 4850\end{array}$

Because of the uneven development in the 1970's, it is difficult to assess whether the forecast (or the projection) is too low or too high. Taking into account the fact that the yield is already higher than the forecast in the recorded herds, and even higher in many other herds, it is certainly possible to obtain the yield forecast. Breeding, and the improvement of the stock due to the decrease in the number of dairy cows, are obviously going to guarantee that development will proceed as forecasted. 


\section{3. Total milk production}

From the record production of 3715 mill. litres in 1964, milk production decreased 17.5 per cent by 1974 , and this decrease was almost linear (Figure 1). However, there was a change in this trend in 1975 when production increased slightly.

The forecast of the milk production should not be based solely on production but also on the number of dairy cows and the average milk yield. If the average yield is 48501 ., 600000 cows produce 2910 mill. l. of milk. To keep the production at the present level of 3100 mill. 1. would require 640000 cows.

It should be kept in mind that, according to the incomes law of 1977, the ceiling for the milk marketed is 2710 mill. 1. in 1979, 2675 mill. 1 . in 1980 and 2675 mill. l. in 1981. Accordingly the corresponding total milk production would be 2820,2800 and 2775 mill. 1. respectively. Production over and above these quantities would have to be exported at the farmers' expense.

The reliability of this forecast can best be evaluated by comparing it to the development of the milk consumpiton.

Measured in fat content, the self-sufficiency in milk fluctuated between 120 and 126 per cent in the 1960's. Thus, despite the decrease in production, self-sufficiency did not decline.

This was due to the decrease in the consumption of fluid milk and butter, which was compensated by an increase in cheese consumption. The trend was similar in the 1970's:

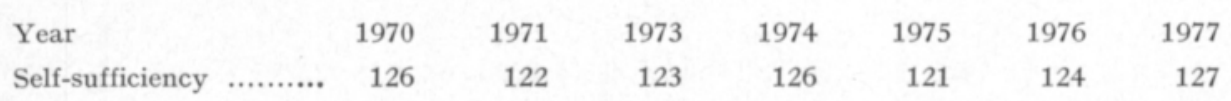

The constant consumption of fluid milk products, the decrease in butter consumption and the increase in cheese consumption have been characteristic of the milk concumption as a whole. This development, it has been assumed, will continue, except that the consumption of fluid milk will also decrease slightly, perhaps 10 per cent, in ten years. According to the forecasts, the milk consumption will be about 2340 mill. 1. in total in 1985, compared to 2560 mill. 1. in 1975 . The decrease would be 8.6 per cent.

If the milk production is 2910 mill. litres (3000 mill. kg.) in 1985, selsufficieney would be 124 per cent. If the milk consumption would stay at the same level as it was in 1975 , self-sufficiency would be 114 per cent. The forecast for milk consumption may be too pessimistic, because recently a target has been set to keep, among other things, the butter consumption at a level of 60 mill. $\mathrm{kg}$ per year. If this target is achieved the milk consumption will remain constant.

The above considerations indicate that the projection of milk production (600 000 dairy cows and 2910 mill. litres of milk) accords with the assumption of an unchanged agricultural policy: self-sufficiency will stay at about $120-125$ per cent. If the target is at a lower level of selfsufficiency, the pace of the reduction in milk production has to be speeded up somewhat. 


\section{Beef production}

An independent projection cannot be made for beef: it must be based on the number of dairy cows and the average slaughter weights.

The development of slaughter weights has been, according to the slaughter statistics, rather linear, and projecting this trend to 1985 gives a forecast of $200 \mathrm{~kg}$. The materialization of this forecast is questionable. Only the average slaughter weights of dairy cows have reached that figure. Since the weight of cows is increasing, and since production fees are paid for slaughterings of $160 \mathrm{~kg}$ or over, there exists an incentive to raise the slaughter weights. The decrease in the supply of calves has an obvious effect in the same direction.

Above all, the slaughter weights increase because heavier animals are reared, as can be seen from Table 2. The slaughtering of small calves seems to have reached a minimum level, and the slaughtering of beef calves of below $80 \mathrm{~kg}$ and of $80-120 \mathrm{~kg}$ is obviously going to decrease; thereby increasing the average slaughter weight.

The slaughter weights of cows, bulls and heifers can be assumed to continue to rise a little. In fact, if the slaughtering of small and beef calves decreases, the average slaughter weight may rise to $190-195 \mathrm{~kg}$. The weight of $200 \mathrm{~kg}$ given by the linear trend seems to be too high. In the following a forecast of $190 \mathrm{~kg}$ will be applied. Even that may be too high.

Table 2. Distribution of animals slaughtered in $1967-76,1000$ pcs.

\begin{tabular}{rrrrrrr}
\hline Year & Dairy cows & $\begin{array}{c}\text { Heifers } \\
\text { and bulls }\end{array}$ & $\begin{array}{c}\text { Young } \\
\text { oxen }\end{array}$ & $\begin{array}{c}\text { Calves } \\
\text { under } 80 \text { kg. }\end{array}$ & $\begin{array}{c}\text { Small } \\
\text { calves }\end{array}$ & Total \\
\hline 1967 & 166 & 204 & 110 & 242 & 71 & 793 \\
68 & 151 & 230 & 101 & 187 & 51 & 720 \\
69 & 203 & 306 & 115 & 198 & 43 & 865 \\
70 & 216 & 293 & 93 & 132 & 30 & 764 \\
71 & 170 & 361 & 80 & 100 & 22 & 733 \\
72 & 192 & 338 & 123 & 69 & 18 & 740 \\
73 & 166 & 293 & 127 & 49 & 11 & 646 \\
74 & 217 & 325 & 150 & 65 & 23 & 780 \\
75 & 182 & 325 & 133 & 59 & 26 & 725 \\
76 & 172 & 346 & 100 & 40 & 27 & 685 \\
\hline
\end{tabular}

The number of animals slaughtered obviously depends on the number of dairy cows, because the stocks of pure beef breeds are still very small. There is no clear picture of this ratio, nor is it easy to estimate. It has been concluded that the number of animals slaughtered would be, roughly, 90 per cent of the stock of dairy cows.

If there are 600000 cows in 1985 , there will be 540000 slaughterings and the beef production will be $\mathbf{1 0 2 . 6}$ mill. $\mathrm{kg}$. If the stocks of dairy cows continue to decrease, the net decrease has to be added to the beef production. For example, a decrease of 10000 cows per year makes an additional 2 mill. $\mathrm{kg}$. of beef. The final beef production would in that case be about 105 mill. $\mathrm{kg}$. or slightly less than previously estimated. 


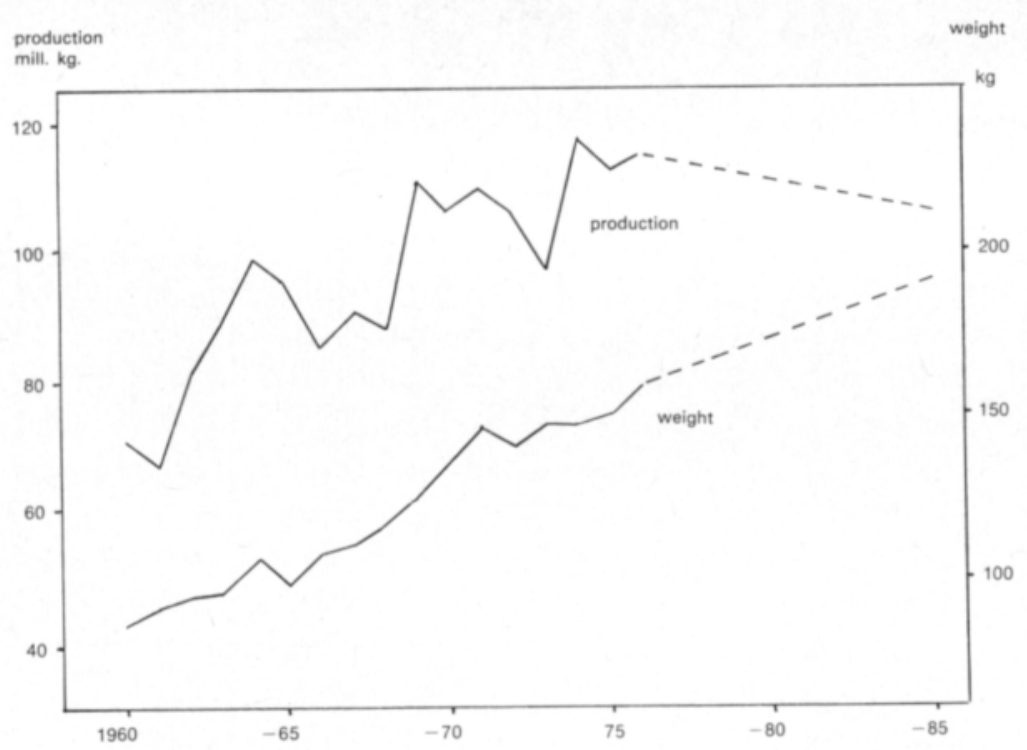

Figure 2. Beef production and average slaughter weights in $1960-76$ and forecast for 1985 .

Pure beef breeding is not taken into account in this forecast as it has formed a rather small part of the beef production. Because the demand for beef in 1985 will obviously be higher than the supply, if the demand for meat can not be directed to pork by price policy measures, an attempt should be made to increase the production of pure beef. This would serve to lower the import pressure on beef.

\section{Pork production}

Pork production is, biologically, much more elastic than milk or beef production. If the proper economic conditions exist, production may be increased rather rapidly. Projections are there fore not advisable and longterm forecasts are based mainly on consumption forecasts. It is assumed that production will be adjusted to the development of consumption by means of agricultural policy measures.

Pork production has, so far, developed in a rather restrained manner. A need for export has existed at times, but it has been relatively small compared to the production. An even more stable growth of production might have been achieved if the setting of the producer price could have been based solely on the requirements of the production policy. Agricultural policy in Finland is conducted in a way that takes into account the whole agricultural sector. Occasionally there is a need to raise some producer prices above the average, which is done by ignoring the price increases of other products. In this way the rise in the producer price of pork has in some years been less than the rise of producer costs would have indicated. This has caused some unnecessary fluctuations in the production. But, as a whole, the price policy for pork has been successful. 


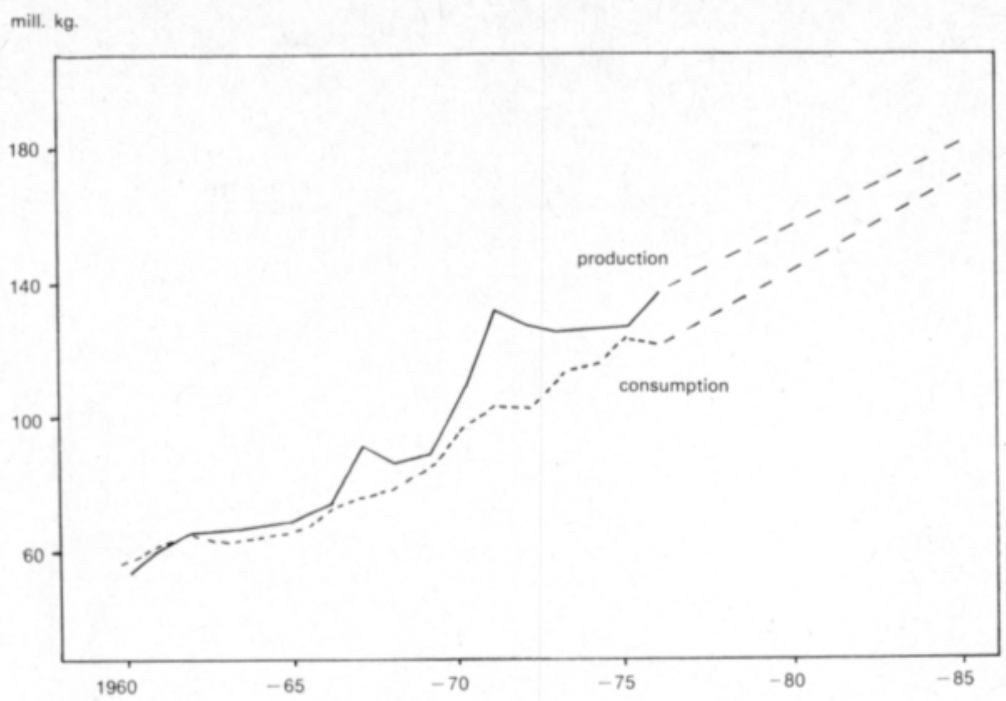

Figure 3. Pork production and consumption in $1960-76$ and a forecast for 1985 .

Pork consumption is a matter of income and the price ratio of beef and pork. As has been indicated earlier, the domestic beef supply will instead of increasing. This forces us to raise the price of beef faster than that of pork. Production costs of beef are higher than those of pork, and so, for natural reasons, pork should be more profitable than beef.

It is obvious that the increase in the meat consumption - which depends on the economic growth - will be directed to pork. The annual growth in per capita pork consumption has been about $1 \mathrm{~kg}$. If this continues as assumed, it will be $35 \mathrm{~kg}$ in 1985 . Total consumption will then be 171 mill. $\mathrm{kg}$.

If the past trend is projected, a production of $180 \mathrm{mill} . \mathrm{kg}$. in 1985 is obtained. This will exceed consumption but a slight surplus is acceptable. According to the income law, the export ceiling of pork is 14 mill.kg. in 1979, 13 mill. kg. in 1980 and 12 mill. kg. in 1981. On the other hand, the forecast of 180 mill. kg. can also be considered an average forecast which may also be easily exceeded.

\section{Egg production}

Our agricultural policy has been less successful in directing the egg production. In a few years prodouction has increased so much that self-sufficiency is already 165 per cent. Since the export of eggs is very uneconomical, reducing the production has been established as a target for the years to come. The income law of 1977 stipulates that the state supported export of eggs will be 15 mill. kg. in 1979, 12 mill. kg. in 1980 and 10 mill. kg. in 1981. Exports above these limits have to be financed by the producers.

The growth in consumption sets the framework for the development of production. According to a forecast made two years ago, consumption per capita will grow to $13 \mathrm{~kg}$. by 1985 . However, this forecast may be too opti- 


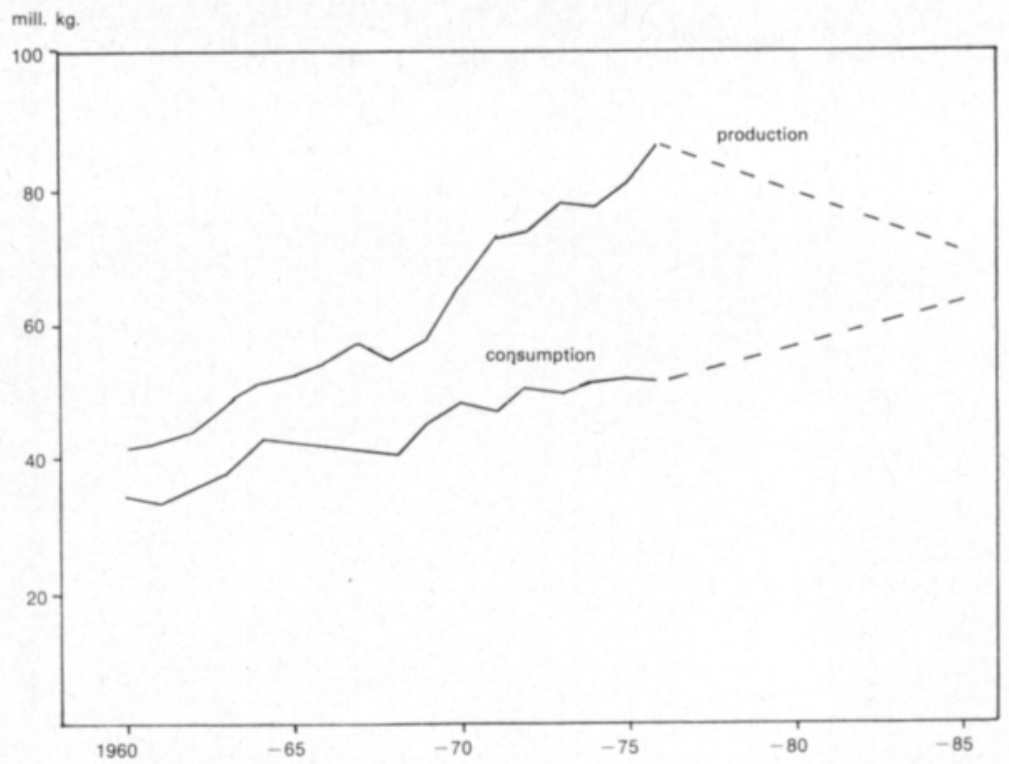

Figure 4. Egg production and consumption in $1960-76$ and a forecast for 1985 .

mistic as consumption has been rather stable, $10-11 \mathrm{~kg}$. during the 1970 's. It may be rather difficult to raise the consumption with the aid of a price policy because the price is already rather low.

Production forecasts may be made based on the consumption forecast and the export ceiling (or about $110 \%$ self-sufficiency). Consumption will be about 63 mill. $\mathrm{kg}$. in 1985 . If state subsidised exports would stay at a level of 10 mill. kg., production could be $70-75$ mill. $\mathrm{kg}$. Below, a forecast of 70 mill. kg. is applied.

\section{Poultry meat}

It is assumed that the poultry meat production may be adjusted to the demand in the same way as that of pork. The poultry meat consumption is still low - less than $3 \mathrm{~kg}$. per capita/yr. Broiler production, which accounts for $2 / 3$ of all poultry meat, has, however, increased rather rapidly. It can be assumed that the demand for broiler is on the increase. This is indicated in a study by IкÄHeImo and RouhiaInen (1973).

Forecasting the broiler consumption is more or less guess-work. On the basis of historical development, it is estimated that consumption will be $\mathbf{5} \mathbf{~ k g}$. per capita in 1985 or 24 mill. kg. in total. Production will be the same as consumption.

\section{Other meat}

The production of other meat (mutton, horse and reindeer) is about 6 mill. $\mathrm{kg}$. or about 2 per cent of the total meat production. This amount will obviously decrease further. The number of horses, in particular, will fall but it is pos- 
sible that the number of sheep will also decrease despite attemps to revive the mutton production.

Other kinds of meat play an insignificant role in the production forecasts and hardly affect the total production. In the following, a forecast of $\mathbf{5}$ mill. $\mathrm{kg}$. of other kinds of meat is applied.

\section{Feed input required by animal production}

In order to determine the feed input nedeed for the animal production forecast, two separate studies on the development of feed efficiency were made (HAgGren 1977, Kettunen 1977). There are many difficulties in measuring feed efficiency, and the results have to be considered as being only preliminary.

Feed efficiency improves in general as a result of selective breeding and more complex feeding methods. The feed efficiency rate for beef is the only one which deteriorates because of the higher slaughter weights.

At present, half of the feed input is needed for the milk production. However, this is estimated to decrease by about 10 per cent by 1985 , due to the decline in milk production and the slight improvement in feed efficiency. The feed use in beef and pork production will, however, increase to such an extent that the feed requirement of the animal production forecast will increase by about one per cent.

Table 3. Animal production and feed use in 1975 and 1985.

\begin{tabular}{|c|c|c|c|c|c|c|}
\hline & \multicolumn{2}{|c|}{1975} & \multirow[b]{2}{*}{ mill. f.u. } & \multicolumn{3}{|c|}{1985} \\
\hline & $\begin{array}{l}\text { Production } \\
\text { mill. kg. }\end{array}$ & $\begin{array}{c}\text { Feed use } \\
\text { f.u. } / \mathrm{kg} \text {. }\end{array}$ & & $\begin{array}{l}\text { Production } \\
\text { mill. kg. }\end{array}$ & $\begin{array}{l}\mathrm{Fe} \\
\text { f.u./kg. }\end{array}$ & $\begin{array}{l}\text { use } \\
\text { mill. f.u. }\end{array}$ \\
\hline Milk $^{1}$ ) $\ldots \ldots \ldots \ldots \ldots$ & 3164 & 0.83 & 2626 & 2910 & 0.81 & 2357 \\
\hline Beef ................. & 112 & 11.50 & 1288 & 105 & 13.80 & 1449 \\
\hline Pork ................ & 127 & 5.28 & 671 & 180 & 4.77 & 859 \\
\hline Hens' meat ....... & 5 & 7.90 & 40 & 5 & 7.90 & 40 \\
\hline Broiler ............. & 6 & 4.00 & 24 & 20 & 3.60 & 72 \\
\hline Eggs...$\ldots \ldots \ldots \ldots$ & 80 & 3.56 & 285 & 70 & 3.08 & 216 \\
\hline Horses $\left.^{2}\right) \quad \ldots . \ldots . .$. & \multicolumn{2}{|c|}{ (38 $000 \mathrm{pcs})$} & 76 & \multicolumn{2}{|c|}{ (30 000 pcs) } & 60 \\
\hline Sheep $\left.^{2}\right)$.............. & \multicolumn{2}{|c|}{$(56000 \mathrm{pcs})$} & 32 & $(50000$ & pcs) & 29 \\
\hline Total $\ldots . . . \ldots \ldots . . .$. & & & 5042 & & & 5082 \\
\hline
\end{tabular}

1) In case of milk, mill. litres and f.u./litre.

${ }^{2}$ ) For horses and sheep, the annual use of feed is estimated.

As it is estimated that the consumption of plant products is about 730 mill. feed units, the total use would be 5800 mill. f. u. in 1985 . According to the projections, the total plant production will be about 6000 mill. feed units in 1985 if the arable area stays at the present level of 2.30 mill. ha. This means that there would be an extra 200 mill. feed units which could be used for additional animal production or exported. This estimate is based on a normal yield around which annual fluctuations may be as much as 10 per cent. 


\section{Summary and conclusions}

There are many factors that affect the reliability of forecasts. The normal crop yields should be, in principle, easy to forecast, however, annual fluctuations make it difficult to check the validity of the forecasts. Feed efficiency should also develop smoothly, but, again, this is difficult to verify because of the problems encountered when measuring the quantity and quality of the feed yield. In general, it can be assumed that the production potential increases by 1.5 per cent per year due to the rise in crop yields.

Beginning with the production targets, a forecast is made which proposes the following production levels in 1985: 2910 mill. litres; beef- 105 mill. kg.; pork- 180 mill. kg.; eggs- 70 mill. kg.; and poultry meat- 25 mill. kg. In 1985 , self-sufficiency in milk would be $120-125$ per cent and in pork and eggs about 110 per cent. The grain surplus would be about 200 mill. kg., under normal conditions.

The forecasts are "surprise-freen. What is the likelihood of an essential change occurring in the development of agriculture in the forecasting period? Yields improve due to biological-technological development. The radical rise in fertilizer prices may lead to a decrease in their use causing a decline in yields. An even more important factor may be the restrictions on the use of fertilizers resulting from enviromental concerns. It cannot, however, be forecasted when these restrictions will be enforced.

Another factor that affects the forecasts is economic growth. If this is smaller than assumed, meat consumption, in particular, will grow more slowly than will production. So far, the income distribution has changed in favour of low income families, which has increased meat consumption.

The changes in the production forecast are, on the other hand, rather small. If necessary, the trend can be changed rather easily by means of agricultural policy measures. The supply of energy is of crucial importance; however, Finnish agriculture is capable of adjusting itself to other phenomena rapidly and vigorously.

Acknowledgements. This paper is a summary of a research project which deals with forecasts of agricultural production. I want to express my gratitude to the staff of the Agricultural Economics Research Institute which has in many ways helped in this project. Especially I wish to mention Seppo Aaltonen, Alan Buff, Erik Haggrén, Merja Manninen, Markku Nevala and Juhani Rouhiainen. The project was partly financed by the Ministry of Agriculture and Forestry and the Foundation of Kyösti Haataja. This support is greatly appreciated.

\section{REFERENCES}

HAAPA, M. \& MajJALA, K. 1977. Eri kotieläintuotteiden vaatimat rehuyksikkömäärät tuoteyksikköä kohti. Mimeog. 45 p.

HAGGREN, E. 1977. Kotieläintuotannon rehuhyötysuhde ja sen tuleva kehitys (Feed conversion rates in animal production and their development). Maatalouden taloudellisen tutkimuslaitoksen tiedonantoja no $49.87 \mathrm{p}$.

HaGgren, E. \& Kettunen, L. 1976. Maataloustuotteiden kulutusennusteet vuoteen 1976 (Consumption forecasts of agricultural products by 1985). Maatalouden taloudellisen tutkimuslaitoksen tiedonantoja no 37.48 p. 
IкÄнетмо, E. \& Rouhiainen, J. 1973. Siipikarjanlihan taijonnasta ja kysynnästä Suomessa vv. 1966-68. (Summary: Supply and Demand of Poultry Meat in Finland 1966-68). J. Scient. Agric. Soc. Finl. 45: 272-283.

Kettunen, L. 1976. Consumption of agricultural products in Finland in 1985 . J. Scient. Agric. Soc. Finl. 48: 386-394.

- 1977. Feed efficiency and its development in animal production. J. Scient. Agric. Soc. Finl. 49: 374-381.

- 1978. Maataloustuotannon kehitys vuosina 1975-85. Maatal. Taloud. Tutk.lait. Julk. 37: 101-117.

Mela, T. \& HaApalainen, M. 1976. Hehtaarisatojen ja tärkeimpien satoon vaikuttavien tekijöiden kehitys vuosina 1956-75 ja ennuste vuoteen 1985. Maatal. Tutk.kesk. Kasvinvilj.lait. Tied. 4. $60 \mathrm{p}$.

Ms received September 27, 1978.

SELOSTUS

\section{Maataloustuotannon kehitys Suomessa 1975-85}

LAURi KetTunen

Maatalouden taloudellinen tutkimuslaitos, Rukkila, 00001 Helsinki 100

Artikkeli on ilmestynyt suomenkielisenä julkaisussa »Maatalouspolitiikan saroilta», Maatalouden taloudellisen tutkimuslaitoksen julkaisuja no 37 , Helsinki 1978, s. $100-117$. 